\title{
THE STATEMENT OF CASH FLOWS
}

\author{
Associate Professor PhD Cernusca Lucian University „Aurel Vlaicu” of Arad, \\ luciancernusca_ro@yahoo.com \\ Professor PhD Mates Dorel, West University of Timisoara
}

\begin{abstract}
In today's business environment, it is not enough simply to monitor earnings and earning per share measurements. An entity's financial position and especially its inflows and outflows of cash are also critical to its financial success. The statement of cash flows alerts financial statement readers to increases and decreases in cash as well as to the reasons and trends for the changes. This brief article is going to present a historical perspective on this financial statement, the statement of cash flows' purpose and, finally, the way of systematizing and reporting the financial information on it.
\end{abstract}

\section{A Historical Perspective on the Statement of Cash Flows}

The statement of cash flows is a relatively new financial statement. In 1987, the Financial Accounting Standards Board (FASB) issued an accounting standard, FASB Statement no. 95, requiring that the statement of cash flows be presented as one of the three primary financial statements. Previously, companies had been required to present a statement of changes in financial position, often called the funds statement. In 1971, APC Opinion no. 19 made the funds statement a required financial statement although many companies had begun reporting funds flow information several years earlier.

The funds statement provided useful information, but it had several limitations. First, APB Opinion no. 19 allowed considerable flexibility in how funds could be defined and how they were reported on the statement. As a result, many companies reported on a working-capital basis (current assets minus current liabilities), whereas other reported on a cash basis or some other basis. Further, in each case, the individual company selected its own format. The inconsistency across companies made comparisons difficult. Second, the funds statement, even when prepared on a cash basis, did not provide a complete and clear picture of a company's ability to generate positive cash flows. One reason is that APB Opinion no. 19 required that all investing and financial activities be reported in the statement, even those that did not affect cash or working capital. Another problem was that the funds statement usually included two sections: sources (inflows) and uses (outflows) of funds. Thus, the amount of working capital or cash provided or used by each major type of activity (operating, investing and financing) was not identified. The limitations of the funds statement often made it difficult to assess a company's ability to generate sufficient cash. Some companies were able to report favorable earnings in the income statement, even while experiencing serious cash flows problems that were not readily apparent from the information reported in the funds statement.

\section{The Purpose of the Statement of Cash Flows}

The statement of cash flows, as its name implies, summarizes a company's cash flows for a period of time. The statement of cash flows explains how a company's cash was generated during the period and how that cash was used. Even if the statement of cash flows seems to be a replacement for the income statement, the two statements have two different objectives.

The income statement measures the results of operations for a period of time. Net income is the accountant's best estimate at reflecting a company's economic performance for a period. The income statement provides details as to how the retained earnings account changes during a period and ties together, in part, the owner's equity section of comparative balance sheets. The statement 
of cash flows provides details as to how the cash account changed during a period. The statement of cash flows reports the period's transactions and events in terms of their impact on cash. Also, this financial statement provides important information from a cash-basis perspective that complements the income statement and balance sheet, thus providing a more complete picture of a company's operations and financial position. It is important to note that the statement of cash flows does not include any transactions or accounts that are not already reflected in the balance sheet or the income statement. Rather, the statement of cash flows simply provides information relating to the cash flow effects of those transactions.

Users of financial statements, particularly investors and creditors, need information about a company's cash flows in order to evaluate the company's ability to generate positive net cash flows in the future to meet its obligations and to pay dividends. In some cases, careful analysis of cash flows can provide early warning of impending financial problems.

\section{Information Reported in the Statement of Cash Flows}

Accounting standards include specific requirements for the reporting of cash flows. The inflows and outflows of cash must be divided in three main categories, namely operating activities, investing activities and financing activities. Further, the statement of cash flows is presented in a manner that reconciles the beginning and ending balances of cash and cash equivalents. Cash equivalents are short-term, highly liquid investments that can easily be converted into cash. Generally, only investments with maturities of three months or less qualify as cash equivalents, such as: Treasury bills, money market funds or commercial paper. The general format for the statement of cash flows is presented in the exhibit below (Exhibit 1):

Cash provided by (used in):

Operating activities

Investing activities

Financing activities

Net increase (decrease) in cash and cash equivalents

Cash and cash equivalents at beginning of year

Cash and cash equivalents at end of year

Exhibit 1: General Format for a Statement of Cash Flows

The three categories of activities (operating activities, investing activities and financing activities) generating inflows and outflows of cash are very suggestively presented in the exhibit from below (Exhibit 2):

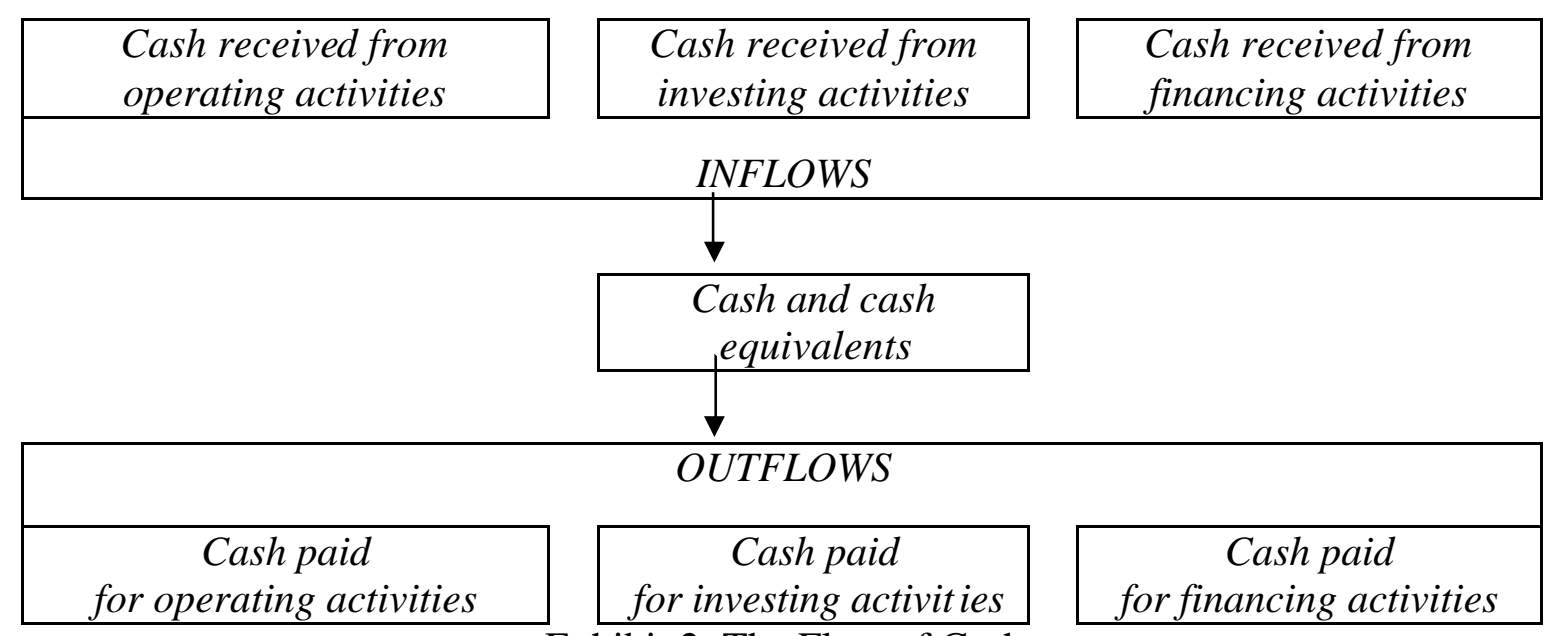

Exhibit 2: The Flow of Cash 
Operating activities include those transactions and events that enter into the determination of net income. Cash receipts from the sale of goods or services are the major cash inflows for most businesses. Other inflows are cash receipts for interest revenue, dividend revenue and similar items. Major outflows of cash are for the purchase of inventory and for the payment of wages, taxes, interest, utilities, rent and similar expenses.

Transactions and events that involve the purchase and sale of securities, property, buildings, equipment and other assets not generally held for resale and the making and collecting of loans are classified as investing activities. These activities occur regularly and result in cash inflows and outflows. They are not classified under operating activities because they relate only indirectly to the entity's central, ongoing operations, which usually involve the sale of goods and services. The analysis of investing activities involves identifying those accounts on the balance sheet relating to investments (typically long-term asset accounts) and then explaining how those accounts changed and how those changes affected the cash flows for the period.

Financing activities include transactions and events whereby resources are obtained from or paid to owners (equity financing) and creditors (debt financing). Dividend payments, for example, fit this definition. The receipt of dividends and interest and the payment of interest are classified under operating activities simply because they are reported as a part of income on the income statement. The receipt or payment of the principal amount borrowed or repaid (but not the interest) is considered a financing activity.

\begin{tabular}{|l|}
\hline Operating Activities \\
Cash receipts from: \\
Sales of goods and services \\
Interest revenue \\
Dividend revenue \\
Sale of investments in trading securities \\
Cash payments to: \\
Suppliers for inventory purchases \\
Employees for services \\
Governments for taxes \\
Lenders for interest expense \\
Brokers for purchase of trading securities \\
Others for other expenses (utilities, rent) \\
Investing Activities \\
Cash receipts from: \\
Sale of property, plant and equipment \\
Sale of a business segment \\
Sale of investments in securities other than trading securities \\
Collection of principal on loans made to other entities \\
Cash payments to: \\
Purchase property, plant and equipment \\
Purchase debt or equity securities of other entities \\
Make loans to other entities \\
Financing Activities \\
Cash receipts from: \\
Issuance of own stock \\
Borrowing (bonds, notes, mortgages) \\
Cash payments to: \\
Repayolders as dividends \\
Repurchase an entity's own stock (treasury stock) \\
\hline
\end{tabular}

Exhibit 3: Major Classifications of Cash Flows 
The major classifications of cash flows, taking into consideration the three types of activities, are presented in the exhibit above (Exhibit 3).

Analyzing the cash flow effects of financing activities involves identifying those accounts relating to financing (typically long-term debt and common stock) and explaining how changes in those accounts affected the company's cash flows. Some investing and financing activities do not affect cash. For example, equipment may be purchased with a note payable or land may be acquired by issuing stock. These non cash transactions are not reported in the statement of cash flows. However, if a company has significant non cash financing and investing activities, they should be disclosed in a separate schedule or in a narrative explanation. The disclosures may be presented below the statement of cash flows or in the notes to the financial statements.

\section{The Process of the Statement of Cash Flows' Elaboration}

Taking into consideration, the information presented in the balance sheet and in the income statement, there is a six-step process in preparing the statement of cash flows. These steps consist of:

1. Compute the change in the cash and cash equivalent accounts for the period of the statement. Seldom is one handed a check figure in real life, but such is the case when preparing a statement of cash flows. The statement of cash flows is not complete until it is explained the change from the beginning balance in the cash account to the balance at year-end.

2. Convert the income statement from an accrualbasis to a cash-basis summary of operations. This is done in three steps, namely: eliminate from the income statement those expenses that don't involve cash (such non cash items would include depreciation expense that does not involve an outflow of cash in the current period even though income was reduced); eliminate from the income statement the effects of non operating activity items (such items include gains and losses associated with the retirement of debt); identify those current assets and current liability accounts associated with the income statement accounts and adjust those income statement accounts for the changes in the associated current assets and current liabilities. For example, sales will be adjusted for the change between the beginning and ending balance in accounts receivable to derive the cash collections for the period. The final result will be cash flows from operating activities.

3. Analyze the long-term assets to identify the cash flow effects of investing activities. Changes in property, plant and equipment and in long-term investments may indicate that cash has either been spent or been received.

4. Analyze the long-term debt and stockholders' equity accounts to determine the cash flow effects of any financing transactions. These transactions could be borrowing or repaying debt, issuing or buying back stock or paying dividends.

5. Prepare a formal statement of cash flows by classifying all cash inflows and outflows according to operating, investing and financing activities. The net cash flows provided by (used in) each of the three main activities of an entity should be highlighted. The net cash flows amount for the period is then added (subtracted) from the beginning cash balance to report the ending cash balance.

6. Report any significant investing or financing transactions that did not involve cash in a narrative explanation or in a narrative explanation or in a separate schedule to the statement of cash flows. This would include such transactions as the purchase of land by issuing stock or the retirement of bonds by issuing stock.

\section{The Statement of Cash Flows and Decisions}

Analysis using cash flow information is often restricted to examining the relationships among the categories in the statement of cash flows. It is not performed vertical or horizontal analysis because, unlike the balance sheet and income statement, there is no guarantee that a specific number from the statement of cash flows will consistently serve as the denominator for 
scaling purposes. For example, all balance sheet accounts are compared to total assets when preparing a vertical analysis of the balance sheet because the total assets are always going to be the biggest number on the balance sheet. The same is true for the income statement. Revenue is used because it is, in almost every case, the biggest number on the income statement. In the case of the statement of cash flows, some years the cash flow from operations may be the largest number on the statement. In subsequent years, that number may be negative. Thus, horizontal and vertical analyses are rarely performed using the statement of cash flows because of scaling problems.

Although the statement of cash flows, like the other financial statements, reports information about the past and careful analysis of this information can help investors, creditors and others assess the amounts, timing and uncertainty of future cash flows. Specifically, the statement helps users answer questions such as how a company is able to pay dividends when it had a net loss or why a company is short of cash despite increased earnings. A statement of cash flows may also show that external borrowing or the insurance of capital stock provided the cash from which dividends were paid even though a net loss was reported for that year. Similarly, a company may be short on cash, even with increased earnings, because of increased inventory purchases, plant expansion or debt retirement.

Trends are often more important than absolute numbers for any one period. Accordingly, cash flow statements are usually presented on a comparative basis. This enables users to analyze a company's cash flows over time. Because companies are required to highlight cash flows from operating, investing and financing activities, a company's operating cash flows and investing and financing policies can be compared with those of other companies. It could be learned much about a company by examining patterns that appear among the three cash flow categories in the statement of cash flows. Thus, there are more patterns regarding the cash flows from the three types of activities. The exhibit from below (Exhibit 4) shows eight possible cash flow patterns and provides some insight into what each cash flow pattern indicates about the company:

\begin{tabular}{|c|c|c|c|l|}
\hline No. & $\begin{array}{c}\text { Cash Flows } \\
\text { from } \\
\text { Operating }\end{array}$ & $\begin{array}{c}\text { Cash Flows } \\
\text { from } \\
\text { Investing }\end{array}$ & $\begin{array}{c}\text { Cash } \\
\text { Flows from } \\
\text { Financing }\end{array}$ & \multicolumn{1}{|c|}{ General Explanation } \\
\hline 1 & + & + & + & $\begin{array}{l}\text { Company is using cash generated from } \\
\text { operations, from sale of assets and from } \\
\text { financing to build up pile of cash (very liquid } \\
\text { company) possibly looking for acquisition. }\end{array}$ \\
\hline 2 & + & - & - & $\begin{array}{l}\text { Company is using cash flows generated from } \\
\text { operations to buy fixed assets and to pay } \\
\text { down debt or pay owners. }\end{array}$ \\
\hline 3 & + & + & - & $\begin{array}{l}\text { Company is using cash from operations and } \\
\text { from sale of fixed assets to pay down debt or } \\
\text { pay owners. }\end{array}$ \\
\hline 4 & + & - & + & $\begin{array}{l}\text { Company is using cash from operations and } \\
\text { from borrowing or from owner investment) } \\
\text { to expand. }\end{array}$ \\
\hline 6 & - & + & + & $\begin{array}{l}\text { Company's operation cash flow problems are } \\
\text { covered by sell of fixed assets, by borrowing } \\
\text { or by stockholder contributions. }\end{array}$ \\
\hline & - & - & + & $\begin{array}{l}\text { Company is growing rapidly, but has } \\
\text { shortfalls in cash flows from operations and } \\
\text { from purchase of fixed assets financed by } \\
\text { long-term debt or new investment. }\end{array}$ \\
\hline
\end{tabular}




\begin{tabular}{|c|c|c|c|l|}
\hline 7 & - & + & - & $\begin{array}{l}\text { Company is financing operating cash flow } \\
\text { shortages and payments to creditors and/or } \\
\text { stockholders via sale of fixed assets. }\end{array}$ \\
\hline 8 & - & - & - & $\begin{array}{l}\text { Company is using cash reserves to finance } \\
\text { operation shortfall and pay long-term } \\
\text { creditors and / or investors. }\end{array}$ \\
\hline
\end{tabular}

Exhibit 4: Analysis of Cash Flows Statement

Positive cash flows from operations are necessary if a company is to succeed over the long term. The most common pattern is a positive operating activities cash flow and negative cash flows from investing and financing activities. Companies use cash flows from operations to purchase fixed assets or to pay down debt. Growing companies prefer a positive financing activities cash flow and negative cash flows from operating and investing activities. Cash is being borrowed to cover a shortage of cash from operations as well as to purchase fixed assets.

In conclusion, conducting financial statement analysis using information from the statement of cash flows is more difficult than analyses using information from the income statement and the balance sheet. The primary reason is that it is common for cash flows for certain categories to be negative, thereby making interpretation difficult. Nevertheless, an analysis of the relationship among the categories on the statement of cash flows can provide insight into a company's performance.

\section{References}

1.Walter, T. Harrison jr., Charles, T. Horngren, Financial Accounting Second Edition, New Jersey, Prentice Hall Englewood Cliffs

2.Nobes, C.W., Parker, R., 2000, Comparative International Accounting, Editura Prent ic Hall

3.Albrecht, S., Stice, J., Stice, E., Skousen, F., Accounting Concepts and Applications Edition 8, South-Western, Thomson Learning

4.*** 2005, Consilier Management Financiar, Editura Rentrop \& Straton

5.*** 2005, Standardele Internationale de Raportare Financiara (IFRS), Editura CECCAR 